\title{
UMA TRAJETÓRIA DE TRABALHO E SUCESSO
}

\author{
Isabel Amélia Costa Mendes ${ }^{1}$ \\ Maria Helena Palucci Marziale ${ }^{2}$
}

A proposta deste editorial é conduzir o leitor a uma viagem no tempo.

Estamos em 26 de dezembro de 1951. A Lei Estadual 1467 cria a estrutura didático-administrativa da Faculdade de Medicina de Ribeirão Preto da Universidade de São Paulo (FMRP/USP) e, anexa a ela, a Escola de Enfermagem de Ribeirão Preto (EERP/USP).

A Prof ${ }^{a}$ Glete de Alcântara é convidada pelo Prof. Dr. Zeferino Vaz, diretor da FMRP/USP, para organizar e dirigir a nova Escola de Enfermagem.

10 de agosto de 1953: início do curso de graduação em Enfermagem, com 30 vagas. Espelhando o seu espírito de inovação e empreendedorismo, a Prof ${ }^{a}$ Glete de Alcântara introduziu um curso de graduação em Enfermagem diferenciado, objetivando a formação de enfermeiras para a assistência ao paciente em ambiente hospitalar e serviços de saúde e, ainda, capacitadas para o desempenho de funções educativas e administrativas, incluído o ensino e a supervisão do pessoal auxiliar.

A vocação para a pesquisa emerge em período anterior à implantação do curso de graduação em Enfermagem, pelas mãos das Prof $^{\mathfrak{a}}$ Glete de Alcântara, que realiza investigações sobre o conhecimento da população acerca do papel profissional da enfermeira. De posse dos resultados a Prof ${ }^{a}$ Glete de Alcântara elabora estratégias para divulgação da Enfermagem, com o propósito de elevar o conceito dessa profissional junto à população, bem como recrutar alunos para o curso de graduação.

Acelerando a viagem, passamos rapidamente por:

1954 - o Ministério da Educação e Cultura autoriza o funcionamento do curso de graduação em Enfermagem 1957 - reconhecimento do curso de graduação em Enfermagem

- formatura da I Turma da EERP/USP

- início do curso de Auxiliar de Enfermagem

1960 - promulgação da Lei que dispõe sobre a estrutura didático-administrativa da EERP/USP

1964 - a EERP/USP é desanexada da FMRP/USP.

O tempo corre célere, a EERP/USP transforma-se, amplia-se, renova-se, buscando formar profissionais capazes de responder às diferentes demandas do mercado de trabalho e contribuir para o avanço da Enfermagem Brasileira.

Os horizontes alargam-se com a expansão de vagas no curso de graduação, com o surgimento de cursos de pós-graduação stricto-sensu e lato-sensu e com o estabelecimento de grupos de pesquisa.

1988 marca o reconhecimento formal da Organização Mundial da Saúde à excelência das atividades acadêmicas desenvolvidas pela EERP/USP, designando-a Centro Colaborador para o desenvolvimento da pesquisa em Enfermagem.

A década de 90 caracteriza-se pela expansão dos cursos de doutorado, elevação de titulação e produção

Editores da Revista Latino-Americana de Enfermagem da Escola de Enfermagem de Ribeirão Preto, da Universidade de São Paulo, Centro Colaborador da OMS para o desenvolvimento da pesquisa em enfermagem: ${ }^{1}$ Professor Titular, e-mail: iamendes@eerp.usp.br; ${ }^{2}$ Professor LivreDocente, e-mail: marziale@eerp.usp.br 
científica do corpo docente.

A pesquisa é desenvolvida por $100 \%$ do corpo docente da EERP/USP, fortalecendo e inovando o ensino; a aplicação do conhecimento produzido contribui para a melhoria dos padrões de assistência de enfermagem em suas diferentes vertentes.

Consolidando mais uma vez sua posição de vanguarda na investigação científica e em consonância com as demandas da Organização Mundial da Saúde/Organização Panamericana da Saúde, cria, em 1993, seu órgão de divulgação científica: a Revista Latino-Americana de Enfermagem (RLAEnf), cuja missão é promover a disseminação do conhecimento científico da enfermagem através da publicação arbitrada de artigos que contribuam para a expansão desta área do saber e para a fundamentação das ações profissionais. Circula, primordialmente, na América Latina e em países de língua oficial portuguesa.

2002: novo selo de reconhecimento internacional é agregado à EERP/USP, com o estabelecimento do Capítulo da Sigma Theta Tau International Honor Society of Nursing.

De volta a 2003, a sensação é a de que o tempo transcorre rapidamente, mas graças ao empenho de docentes, alunos e funcionários a EERP/USP tornou-se um centro de excelência, reconhecido nacional e internacionalmente, na formação de recursos humanos para a assistência e o ensino; de investigadores e líderes de grupos de pesquisa, aptos para atuarem num cenário globalizado e contribuírem para a consecução das metas fixadas pela OMS. A RLAEnf, apesar de jovem é a 1ํㅡ revista de Enfermagem a ser classificada padrão "B" de circulação internacional, segundo critérios da CAPES/Qualis e também a primeira em seu segmento a integrar a coleção ScIELO - Scientific Eletronic Library Online.

\section{3: 50 anos de EERP/USP}

15 anos de Centro Colaborador da OMS, pesquisa em Enfermagem 10 anos de RLAEnf

Registramos os agradecimentos a todos os atores que construiram e compõem a história desta Escola. Sejam eles do quadro funcional ou do corpo discente da Unidade, da FMRP/USP, do Hospital das Clínicas-FMRP/USP e de tantos outros serviços de saúde da cidade e região, da OMS/OPS, de instâncias governamentais, de empresas públicas e privadas, da Associação Brasileira de Enfermagem, do Conselho Federal/Regional de Enfermagem. A nossa gratidão à Universidade de São Paulo e aos clientes assistidos nessa longa jornada.

É inegável a satisfação de comemorar 50 anos, em um contexto mundial que privilegia o enfermeiro como o agente capaz de produzir resultados de impacto no processo de atenção à saúde.

No transcorrer deste ano, a RLAEnf trará ao público um pouco mais da história da EERP/USP, em cada um de seus fascículos.

Junte-se a nós na celebração do Jubileu de Ouro da Escola, do 15aaniversário deste Centro Colaborador da OMS e do $1^{\circ}$ decênio da RLAEnf.

Boa leitura! 


\section{A TRAJECTORY OF WORK AND SUCCESS}

Isabel Amélia Costa Mendes ${ }^{1}$

Maria Helena Palucci Marziale ${ }^{2}$

The proposal of this editorial is to conduct the reader to a trip through time.

We are in December 26, 1951. The State Decree number 1467 creates a didactic and administrative structure at the University of São Paulo at Ribeirão Preto School of Medicine (FMRP/USP) and added to it the College of Nursing (EERP/USP).

Professor Glete de Alcântara is invited by Professor Zeferino Vaz, the Dean of the School of Medicine, to organize and direct the new College of Nursing.

In August 10, 1953, the College begins the undergraduate program in Nursing, opening 30 places. Reflecting her spirit of innovation and entrepreneuship, Professor Glete de Alcantara introduced a differentiated nursing undergraduate program aiming at capacitating nurses to provide care to patients at hospitals and health services and also able to perform educative and administrative functions, including teaching and the supervision of the auxiliary personnel.

The vocation for research emerges in the period before the implementation of the undergraduate program, through the hands of Prof ${ }^{a}$ Glete de Alcântara, who investigated the population knowledge on nurses' professional role. Based on the findings of this survey, Professor Glete de Alcântara elaborates strategies to disseminate Nursing, with the purpose to increase the population understanding about this professional as well as at recruiting students to enroll the program.

Accelerating our trip, we go through:

1954 - the Ministry of Education and Culture authorizes the functioning of the nursing undergraduate program.

1957 - the Nursing Undergraduate Program is recognized.

- the graduation of the $1^{\text {st }}$ Nursing Class

- the Program for Auxiliary Nurses is implemented

1960 - the law on the administrative structure of the EERP/USP is promulgated.

1964 - the College of Nursing is detached from the School of Medicine.

The time goes fast and the EERP/USP changes and renovates itself in order to capacitate professionals to respond to different demands of the job market and to contribute to the improvement of Brazilian Nursing.

The horizons are expanded with the increase of places for the undergraduate program, the creation of "stricto sensu" and "lato sensu" graduate programs and the establishment of research groups.

1988 marks the formal recognition of the World Health Organization to the excellence of the academic activities developed by the College that was designated a Collaborating Center for Nursing Research Development.

The 1990s is characterized by the expansion of the doctoral programs, the elevation of the faculty titles as

Editors of Latin American Journal of Nursing of Ribeirão Preto of the University of São Paulo at Ribeirão Preto College of Nursing - WHO Collaborating Centre for Nursing Research Development: ${ }^{1}$ Full Professor, e-mail: iamendes@eerp.usp.br; ${ }^{2}$ Associate Professor, e-mail: marziale@eerp.usp.br. 
well as the scientific production.

$100 \%$ of the faculty members develop research, strengthening and innovating the teaching, the application of the knowledge produced and contributing to improve the standards of nursing care in its different aspects

Consolidating its position of vanguard in scientific investigation in accordance with the demands of the World Health Organization and Pan American Health Organization, the College creates in 1993 the Revista LatinoAmericana de Enfermagem (RLAEnf), a journal with the mission to promote scientific knowledge in Nursing through the publication of peer reviewed articles that contribute to expand this area of knowledge and provide basis for these professionals' actions. The Journal circulates mainly in Latin America and Portuguese speaking countries.

2002: the College establishes the first Chapter of Sigma Theta Tau International Honor Society of Nursing in America Latin.

Coming back to 2003, the sensation is that the time goes fast and due to the efforts of faculty, students and staff, the EERP/USP became a center of excellence, nationally and internationally recognized, especially due to the formation of human resources to provide the care and to teach, of investigators and leaders of research groups able to act in a globalized scenery and to contribute to the achievement of the goals established by the World Health Organization. The Journal, although young, is the first Nursing Journal classified with the rate "B" of international circulation according to the CAPES/Qualis criteria and is the first one in its segment to integrate the ScIELO - Scientific Eletronic Library Online.

\section{3: 50 years anniversary of EERP/USP \\ 15 years anniversary of the WHO Collaborating Center for Nursing Research Development 10 years anniversary of the RLAEnf Journal}

We would like to acknowledge our thankfulness to the actors who constructed and are part of the history of this College. They are members of the body of employees and students of this Unit, of the School of Medicine, of the University Hospital or other health services in the city and region. Also, we thank to WHO/PAHO, the government organs, public and private enterprises, the Brazilian Nursing Association, the Federal/Regional Nursing Council. Our gratitude to the University of São Paulo and to the clients assisted in this long journey.

It is a great satisfaction to commemorate 50 years in a world context that privileges nurses as the capable agents to produce results of impact in the health process.

Through this year, the RLAEnf Journal will publish more of its history in each issue.

Join us to celebrate the Golden Jubilee, the $15^{\text {th }}$ anniversary of this Collaborating Center and the 10 years of this Journal.

We wish you a good reading! 


\section{Una trayectoria de trabajo y suceso}

Isabel Amélia Costa Mendes ${ }^{1}$

Maria Helena Palucci Marziale ${ }^{2}$

La propuesta de este editorial es conducir al lector a un viaje al tiempo.

Estamos en 26 de Diciembre de 1951. La Ley Estadual 1467 crea la estructura didáctico-administrativa de la Facultad de Medicina de Ribeirão Preto de la Universidad de São Paulo (FMRP/USP) y, aneja a ésta, la Escuela de Enfermería de Ribeirão Preto (EERP/USP).

La Prof ${ }^{a}$ Glete de Alcántara es invitada por el Prof. Dr. Zeferino Vaz, decano de la FMRP/USP, para organizar y administrar la nueva Escuela de Enfermería.

10 de agosto de 1953: inicio del programa de pregrado en Enfermería, con 30 plazas. Reflexionando su espíritu de innovación y emprendedorismo, la Profa Glete de Alcántara implementó un programa de pregrado en Enfermería diferenciado, objetivando la formación de enfermeras para la asistencia al paciente en ambiente hospitalar y servicios de salud y, también, capacitadas para el desempeño de funciones educativas y administrativas, incluida la enseñanza y supervisión del personal auxiliar.

La vocación para la investigación emerge en periodo anterior a la implantación del programa de pregrado en enfermería, por las manos de la Prof $\stackrel{a}{ }$ Glete de Alcântara, que desarrolla investigaciones sobre el conocimiento de la

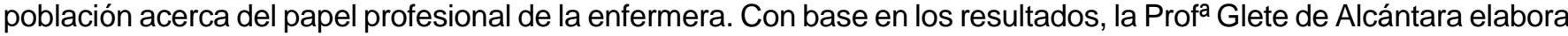
estrategias para divulgación de la Enfermería, con el propósito de elevar la evaluación de esa profesional junto a la población, bién como recrutar alumnos para el programa de pregrado.

Adelantando el viaje, pasamos por:

1954 - el Ministerio de Educación y Cultura autoriza el funcionamiento del programa de pregrado en Enfermería 1957 - reconocimiento del programa de pregrado en Enfermería

- graduación de los alumnos del primero curso de la EERP/USP

- inicio del programa para Auxiliar de Enfermería

1960 - promulgación de la Ley que dispone sobre la estructura didáctico-administrativa de la EERP/USP 1964 - la EERP/USP es separada de la FMRP/USP.

El tiempo vuela y la EERP/USP se transforma, se amplia, se renueva, buscando formar profesionales capaces de responder a las diferentes demandas del mercado de trabajo y contribuir al avance de la Enfermería Brasileña.

Los horizontes se alargan con la expansión de la plazas en el programa de pregrado, con el surgimiento de programas de postgrado stricto-sensu y lato-sensu y con el establecimiento de grupos de investigación.

1988 marca el reconocimiento formal de la Organización Mundial de la Salud a la excelencia de las actividades académicas desarrolladas por la EERP/USP, con su designación como Centro Colaborador para el desarrollo de la investigación en Enfermería.

La década del 90 se caracteriza por la expansión de los programas de doctorado, elevación de la titulación

Editores de la Revista Latinoamericana de Enfermería de la Escuela de Enfermería de Ribeirão Preto de la Universidad de São Paulo, Centro Colaborador de la OMS para el desarrollo de la investigación en enfermería: ${ }^{1}$ Professor Titular, correo electrónico: iamendes@eerp.usp.br;

${ }^{2}$ Professor Libre-Docente, correo electrónico: marziale@eerp.usp.br. 
y producción científica del cuerpo docente.

La investigación es desarrollada por 100\% del cuerpo docente de la EERP/USP, fortalecendo e inovando la enseñanza; la aplicación del conocimiento producido ha contribuido para la mejoría de los padrones de asistencia de enfermería en sus diferentes vertientes.

Consolidando más una vez su posición de vanguarda en la investigación científica y en consonancia con las demandas de la Organización Mundial de la Salud/Organización Panamericana de la Salud, es creado, en 1993, su órgano de divulgación científica: la Revista Latinoamericana de Enfermería (RLAEnf), cuya misión es promover la diseminación del conocimiento científico de enfermería a través de la publicación arbitrada de artículos que van a contribuir para la expansión de ese área del saber y para la fundamentación de las acciones profesionales. Circula, primordialmente, en América Latina y países de lengua oficial portuguesa.

2002: nuevo sello de reconocimiento internacional es agregado a la EERP/USP, con el establecimiento del Capítulo de la Sigma Theta Tau International Honor Society of Nursing.

Retornando a 2003, la sensación es la de que el tiempo transcurre rapidamente, pero gracias al empeño de los docentes, alumnos y funcionários, la EERP/USP ha sido transformada en un centro de excelencia, reconocido nacional e internacionalmente, en la formación de recursos humanos para la asistencia y la enseñanza; bién como de investigadores y líderes de grupos de investigación, aptos para actuar en un cenario globalizado y a contribuir para la consecución de las metas establecidas por la OMS. La RLAEnf, aunque joven, es la 1ํㅡ revista de Enfermería a ser clasificada padrón "B" de circulación internacional, según critérios de la CAPES/Qualis y también la primera en su seguimiento a integrar la colección ScIELO - Scientific Eletronic Library Online.

\section{3: 50 años de EERP/USP}

15 años de Centro Colaborador de la OMS para el desarrollo de la investigación en Enfermería 10 años de RLAEnf

Registramos los agradecimientos a todos los actores que construyeron y componen la historia de esta Escuela, sean ellos del cuadro funcional o del cuerpo discente de la Unidad, de la FMRP/USP, del Hospital de las Clínicas-FMRP/USP y de tantos otros servicios de salud de la ciudad y región, de la OMS/OPS, de instancias gubernamentales, de empresas públicas y privadas, de la Asociación Brasileña de Enfermería, del Consejo Federal/Regional de Enfermería. La nuestra gratitud a la Universidad de São Paulo y a los clientes asistidos en esa larga jornada.

Es innegable la satisfacción de conmemorar 50 años, en un contexto mundial que privilegia el enfermero como el agente capaz de producir resultados de impacto en el proceso de atención a la salud.

En el transcurrir de este año, la RLAEnf va a traer al público un poco más de la história de la EERP/ USP, en cada uno de sus fasciculos.

Juntese a nosotros en la celebración del Jubileo de Oro de la Escuela, del 15aaiversário de este Centro Colaborador de la OMS y del 1을 decenio de la RLAEnf.

Una buena lectura! 